\title{
A DISTANT FINISH LINE FOR WOMEN: GENDER AND THE SPORTS PRESS IN PORTUGAL (1996-2016)
}

\begin{abstract}
In this paper we examine the overall evolution of the coverage of women's sports by the three Portuguese daily sports newspapers ( $A$ Bola, O Jogo and Record), as well as the potential sexual objectification of female athletes. To this end, we conducted an analysis of the news and photographs published by these three daily newspapers over a period of 20 years (1996-2016), based on a random sample. A total of 2,414 news items, including 1,207 articles and 1,207 photographs, were collected from 186 different newspaper editions. The results do not show significant changes in the coverage of women's sports nor a significant decrease in the sexualization of athletes, as signs of sexual objectification remain. The research suggests that policy makers should take active measures to promote equality between women and men in sports journalism.
\end{abstract}

Keywords: Gender; daily sports newspapers; sexual objectification; content analysis; Portugal.

\section{Resumo \\ Uma meta distante para as mulheres: Género e Imprensa Desportiva em Portugal (1996-2016)}

Neste artigo analisamos a evolução global da cobertura do desporto feminino pelos três jornais diários portugueses de desporto ( $A$ Bola, O Jogo e Record), bem como a potencial objectificação sexual de atletas do sexo feminino. Para o efeito, procedemos à análise das notícias e fotografias publicadas por estes três jornais diários durante um período de 20 anos (1996-2016), com base numa amostra aleatória. Um corpus de 2.414 notícias, incluindo 1.207 artigos e 1.207 fotografias, foi constituído a partir de 186 edições de jornais. Os resultados não mostram mudanças significativas na cobertura de desportos femininos nem uma diminuição significativa na sexualização de atletas, uma vez que os sinais de objetificação

* $\quad$ Faculty of Economics (FEUC), University of Coimbra, 3004-512 Coimbra, Portugal.

Electronic address: pdgs@outlook.pt

ORCID: https: / / orcid.org/ 0000-0003-0249-2646

** Centre for Social Sciences (CES), Faculty of Economics (FEUC), University of Coimbra, 3004-512

Coimbra, Portugal.

Postal address: Faculdade de Economia, Av. Dias da Silva, 165, 3004-512 Coimbra, Portugal.

Electronic address: virginia@fe.uc.pt

ORCID: https: / / orcid.org/0000-0003-3838-054X

*** Department of Philosophy, Communication and Information, Faculty of Arts and Humanities, University of Coimbra, 3004-530 Coimbra.

ICNOVA - Institute of Communication of NOVA, Lisbon, Portugal.

Electronic address: mjsilveirinha@gmail.com

ORCID: https: / / orcid.org/0000-0002-0702-3366 
sexual permanecem. A pesquisa sugere que os decisores políticos devem tomar medidas ativas para promover a igualdade entre mulheres e homens no jornalismo desportivo.

Palavras-chave: Género; jornais diários desportivos; objectificação sexual; análise de conteúdos; Portugal.

\section{Resumen \\ Una meta distante para las mujeres: Género y la prensa deportiva en Portugal (1996-2016)}

En este artículo analizamos la evolución global de la cobertura del deporte femenino en los tres diarios deportivos portugueses ( $A$ Bola, O Jogo y Record), así como la potencial objetificación sexual de las atletas femeninas. Con este fin, analizamos las noticias y fotografías publicadas por estos tres diarios por un período de 20 años (1996-2016), en base a una muestra aleatoria. Un corpus de 2.414 noticias, incluyendo 1.207 artículos y 1.207 fotografías, estaba compuesto por 186 ediciones de periódicos. Los resultados no muestran cambios significativos en la cobertura del deporte femenino ni una disminución significativa en la sexualización de las atletas, ya que los signos de objetificación sexual permanecen. La investigación sugiere que los responsables políticos deberían tomar medidas activas para promover la igualdad entre mujeres y hombres en el periodismo deportivo.

Palabras clave: Género; periódicos deportivos diarios; objetificación sexual; análisis de contenido; Portugal.

\section{Introduction}

Ever since Classical Greece, sport has been perceived as a means of glorifying the male body. The exclusion of women represents a logical consequence of this perspective (Gomes et al. 2000). Only from the late $19^{\text {th }}$ century onwards did women begin having the opportunity to practice sports (Borish 1996; Cruz 2001). Female sporting has advanced very slowly, only intensifying in the final quarter of the $20^{\text {th }}$ century. Only at the 2012 Olympic Games did women get to compete in all the sports on the Olympic program. In the case of Portugal, women first had the opportunity to enter the sporting world following the end of the dictatorship, in 1974, as reflected in the numbers: female participants in federated sporting activities practically tripled from 10,867 in 1974 to 30,162 in 1979 (Almeida and Cruz 2010). ${ }^{1}$ The female proportion in federated sports has however remained fairly low, even while progressing from $12.7 \%$ in 1979 to $28.5 \%$ in 2016 (with 168,622 registered female athletes) (IPDJ 2018).

\footnotetext{
The figures presented only include individuals practicing a sport that are registered in the respective sports federation (proven by compulsory sports insurance). Sports federations have the status of sport utility (as entities that promote, regulate and direct, at national level, the practice of the various sports) that applied for public funding during the year. The Federations submit annually their activity plan (including statistical tables) to the Institute of Sports and Youth (Instituto Português do Desporto e da Juventude) for public funding purposes. Federated athletes can be professionals or amateurs.
} 
From the very beginning, the exclusion or conditional integration of women into the different sports, professional or amateur, was socially defined and supervised (LaVoi 2013), in keeping with how sports «help construct ideologies of gender, affect gender relations, and social class hierarchies» (Anderson 2008 apud Eckstein et al. 2010).

Hence the interest in monitoring how the scope of media discourses depicts such sports. Such interest reflects in the vast literature focusing on media coverage of female sports produced over recent decades. The analyses span diverse academic fields and stem from a great variety of approaches and methodologies (Eckstein et al. 2010). In the case of Portugal, although there are some partial studies, with analysis spanning over short periods and specific research questions (Pinheiro 1996; Marivoet 2003; Coimbra 2008; Araújo 2017; Bueno 2017), there has hitherto been no study based on any extensive and longitudinal approach able to characterise the ways in which media coverage has accompanied the growing involvement of women in sport. Our study, therefore, seeks to overcome that shortcoming by covering a sufficiently long period to enable the detection of trends on a random sample of Portuguese most relevant sports journalism.

\section{Women's sport and the media: literature review}

Media outlets, especially in the sports sector, have already been identified as influential in terms of the participation of women in sport in accordance with how the media contribute towards our construction and understanding of the world and the definition of what is considered normal by each culture (Bruce 2013).

Given the decidedly masculine nature of the sporting world, the media, following the traditional perception that men are more active and athletic, cover male sports more than they do to their female counterparts (Centre for Gender Equality 2006). Indeed, the media present men as the lead and most relevant sporting actors (Trigueros 2001 apud Marques 2002), especially as regards those sports deemed as masculine, and the high media profile sports (Louveau 2001). Furthermore, male sports are associated with competition; this being 'frequently justified by the aggressive nature of boys and because this is the quintessential feature of sport' (Gomes et al. 2000). Competition thus becomes an especially male field (Mariovet 2003), which influences the news coverage of sport.

In the case of female sports, we find the opposite features of visibility and ideas of gender. Firstly, countless studies have clearly identified the lack of news coverage of female sports (Pinheiro 1996; Mariovet 2003; Messner 2002; Rawjee et al. 2011; Trolan 2013; Centre for Gender Equality 2016). Despite this, and given the fact that media have recently undergone a significant level of expansion, an increasing level of coverage would be expected. This research thus sought to analyse this rise in visibility through a content analysis of the three daily Portuguese sports newspapers. 
Various studies encapsulate the most recurrent expressions for depicting athletes in media discourses, in particular as «excessive sweat, physical efforts, strong emotions, competitions, mutual rivalries, muscular definition, daringness of character, danger of injuries, [...] emerge as incompatible with the standardised representations of femininity» (Fernandes et al. 2014). This invisibility and the standardisation of a certain ideal of femininity interlinks with other aspects of news coverage. Firstly, women are frequently portrayed as sexual objects and in submissive roles (Waters and Ellis 1996), with the photographs accompanying the texts reinforcing this sexual objectification (Rawjee et al. 2011). This prompts «a seductive women who is first and foremost reserved for a 'decorative' purpose and that of sexual object» (Louveau 2001). Furthermore, according to Cooky et al. (2010), the media represent women as «Others», frequently comparing them with their male peers, sending the message that sports remains a masculine domain even when the focus falls on women's sport. This adds to how, when female athletes are indeed covered by the media, their sporting performance is trivialised alongside the reproduction of stereotypes regarding their performance and looks (Cooky et al., 2010; Rawjee et al. 2011).

As with the news texts, the accompanying photographs display similar characteristics and, even when they do not take on an explicitly sexual character, whenever athletes specifically pose for the camera, the contrasting idea of man/ individual, woman/object is reinforced (Gomes et al. 2000; Pedersen 2002). This produces a ritualization of subordination in the words of Goffman (1976). In economic terms, this is a profitable contrast both for the media and for their advertisers / sponsors (Fink 2015: 338).

These are some of the core issues identified by international research and these findings press for the questioning of the (in)visibility of female athletes in national media, especially against the background of a significant rise in the number of women engaging in federated sports in Portugal and the diversification of media coverage of sporting activities as seen in the vitality of various daily sports newspapers. Furthermore, we seek to understand whether the media coverage of women sports has increased and whether their media representations has undergone any changes in terms of the values attributed to female sporting participation and achievements.

\section{Materials and Methods}

Our longitudinal study is designed to ascertain whether there has been any rise in the number of news items covering female sports alongside any possible changes in the coverage on female athletes and also any significant diversification in the type of sports covered by the media. The hypotheses guiding this research are: 
H1. The coverage by the written sports press perpetuates the stereotypes contained in the distinction between male and female sports through an emphasis on male athletes in certain sports and female athletes in others.

H2. The news coverage of female sports in sport newspapers has not increased in the same proportion as female participation in federated sports.

H3. In the daily coverage of sports press, female athletes are photographed in ways that emphasise their femininity.

H4. Given the rising criticism of the sexualisation of female athletes in media coverage, it has decreased in the period under analysis.

In order to test these hypotheses, we combined traditional content analysis (Weber 1990; Neuendorf 2001) with contextual content analysis (McTavish and Pirro 1990). Content analysis aims to determine who says what, to whom, why, to what extent and with what effect, and has the key advantage of both enabling the organisation of large quantities of text into a small number of content categories and ascertaining their internal and external validity (Weber 1990; Neuendorf 2001). In this framework, codebooks were built for this research. Its main disadvantage stems from the risk of decontextualization and producing reductionist outcomes. We therefore added an exploratory contextual content analytical approach (McTavish and Pirro 1990), aiming to interpret the contextual meaning of the texts and/ or pictures. Finally, we explored the semiotic construction of meaning of a small sample of news photos.

The analytical corpus consisted of the three exclusively sports newspapers published daily in Portugal: A Bola, Record and O Jogo. These newspapers cover a large historical period and their target audience is composed mostly of male readers (Lima 2011; Cardoso et al. 2014, 2016; Santos 2006).

The study covers a 20-year period. Given that these newspapers only became daily in 1995 and on different dates over that year, the analytical period begins on the $1^{\text {st }}$ of January 1996 and ends on the 31st December 2015. Within this twenty-year timeframe, we analysed the editions dated 1 January 1996 and 31 December 2015 , and randomly selected one week from each year as well as three days of each selected week. The total analytical corpus amounted to 186 newspaper editions.

We focused our analysis on the articles in the sample which included photographs corresponding to previously selected sports. Due to the large number of federated sports in Portugal, we selected a sample of ten sports. For this purpose, we took the data from the Portuguese Institute of Sport and Youth (IPDJ 2015, 2018), which identifies the ten sports federations (excluding football ${ }^{2}$ ) with the

The football federation has the most athletes but given the fact that the majority of the contents of these newspapers is on this particular sport (IPDJ 2018), football was excluded as its inclusion would distort the study results. 
largest number of participants in 2014 as: Handball, Volleyball, Basketball, Hiking and Mountaineering (Climbing, Abseiling, and Skyrunning, among others), Swimming, Tennis, Athletics, Karate, Golf and Gymnastics.

Table 1.

Athletes in national Sports Federations in Portugal (1996-2014)

\begin{tabular}{|c|c|c|c|c|c|c|c|c|}
\hline & \multicolumn{4}{|c|}{1996} & \multicolumn{4}{|c|}{2014} \\
\hline & Women & Men & Total & $\begin{array}{l}\% \text { of } \\
\text { Women }\end{array}$ & Women & Men & Total & $\begin{array}{l}\% \text { of } \\
\text { Women }\end{array}$ \\
\hline Handball & 4,418 & 12,968 & 17,386 & 25.4 & 19,828 & 30,286 & 50,114 & 39.6 \\
\hline Volleyball & 3,193 & 3,006 & 6,199 & 51.5 & 23,137 & 19,939 & 43,076 & 53.7 \\
\hline Basketball & 5,654 & 12,396 & 18,050 & 31.3 & 14,262 & 21,328 & 35,590 & 40.1 \\
\hline $\begin{array}{l}\text { Hiking and } \\
\text { Mountaineering }\end{array}$ & n.d.* & n.d. & n.d. & & 10,047 & 22,538 & 32,585 & 30.8 \\
\hline Swimming & 1,729 & 2,588 & 4,317 & 40.1 & 10,597 & 11,098 & 21,695 & 48.8 \\
\hline Tennis & 1,572 & 6,385 & 7,957 & 19.8 & 6,220 & 13,056 & 19,276 & 32.3 \\
\hline Athletics & 3,503 & 7,604 & 11,107 & 31.5 & 5,677 & 9,158 & 14,835 & 38.3 \\
\hline Karate & n.d. & n.d. & n.d. & & 3,824 & 10,910 & 14,734 & 26.0 \\
\hline Golf & 921 & 3,599 & 4,520 & 20.4 & 2,863 & 11,231 & 14,094 & 20.3 \\
\hline Gymnastics & n.d. & n.d. & n.d. & & 11,532 & 2,208 & 13,740 & 83.9 \\
\hline Total & 20,990 & 48,546 & 69,536 & 30.2 & 107,987 & 151,752 & 259,739 & 41.6 \\
\hline
\end{tabular}

n.d. = no data. Source: IPDJ (2018).

Having identified and digitalised the articles, we analysed each sample unit according to the drafted guides (with one code book for written texts and another for photographs). In the case of the written articles, we sought to analyse questions such as: the inclusion of female athletes, references to their femininity, their body or any comparison of their results with men. In photos, we took into account how these reflect the nature of our societies and social relationships (Knoblauch et al. 2008, Paul and Sheets 2012) and aimed to identify the key features of the photograph itself in order to evaluate the qualitative portrayal of their subjects, namely in terms of the possible sexual objectification of female athletes through details such as the focus on specific parts of the athletes' bodies, their heterosexuality or other aspects complying with ideals of female beauty. To this end, the contextual content analysis was followed by a pictorial analysis of the photographs, based on Susan Bordo's (2003) ideas of idealised femininity as text, where the researchers analysed, described and interpreted the portraying of female athletes through the focus on key signs such as poses, clothes or accessories, or camera angles. The dramaturgical perspective of Goffman was also an inspiration for understanding the diversity of bodily practices performed by female athletes in order to fulfil per- 
ceived social expectations about their roles as sportswomen and women (Goffman 1959, 1976). According to Goffman, photographs serve as evidence of the ways individuals present themselves to others $(1976,10)$. Our attention here focuses on the overall figuration and not on the space occupied on the page by the photo.

\section{Results}

The analysis spanned a total of 1,207 articles and 1,207 photographs. The most relevant results are demonstrated below.

Figure 1.

Social actors most referred to by their sex and newspaper

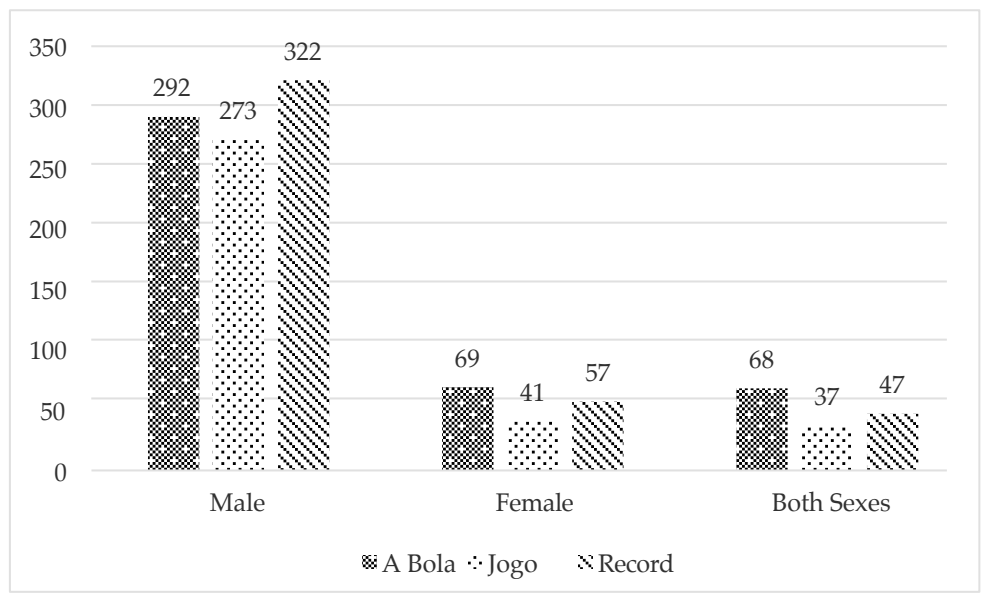

The newspaper A Bola published the largest number of articles on female sport, whether approached exclusively or jointly with male sport (accounting for $31.9 \%$ of the articles, followed by Record with $24.4 \%$ and $O$ Jogo with $22.2 \%$ ). When taking into account only those articles exclusively dedicated to female sports, comparing them with those dedicated to male sports, the newspaper ranking remains the same $-A$ Bola leads with $23.6 \%$, Record with $17.7 \%$ and $O$ Jogo with $15 \%$. Out of the sample of 1,206 articles, only $167(13.8 \%)$ exclusively refer to female sport. When taking into consideration that the rate of female members across the ten sports included for analysis was $44 \%$ in 2016, we clearly see how all newspapers display a deficit in their coverage of female sports and to a very exaggerated extent in the case of the two sports dailies that displayed an equivalence of around a third of the weight that females actually hold in sporting reality. We may interpret these results as a consequence of the newsworthy criteria adopted by the editorial teams, which, in turn, stem from the interests of the respective business groups 
that quite commonly coincide in their ownership of newspapers and sponsorship of sporting teams. Some explain this asymmetric pattern given the professionalization of the respective sports in their male formats, as is the case of Basketball or Handball, and the lacking of such status in female competitions (Coimbra 2008, 7). Deriving from this professionalisation of male sports, there is increased attention in relation to the professional competitions held in these sports, the loci for the cross-referencing of a series of interests of a varying order across the fields of sport, the economy and journalism. We can also add that other male sports are professionalised, such as athletics, tennis or volleyball. In the case of female athletes, this professionalisation is restricted to tennis and athletics only. This will be another potential reason for this disparity between men and women.

Another important dimension of this research involved grasping the trend in female sports coverage over the period under analysis. We found no defined trend upwards or downwards in the number of published news items, which merely vary slightly over the years analysed.

These results are somewhat surprising. Given the rise in the number of female athletes, we would expect an increase in the coverage of female sports, which did not actually take place. The key explanation for the variations verified across our timeframe stems from the international competitions of the analysed sports. Over this two-decade period, the largest number of articles on female sports reflects the World Athletics Championship in 2005, held between 6 and 14 August 2005. However, Mansfield and Curtis (2009) warn that at this type of events athletes may be accompanied by certain gender media stereotypes, especially the idea that, before being athletes, they are first and foremost women.

In addition to the deficit in coverage of female sports in the newspapers, we also saw that women are essentially present in their role as athletes $(83.2 \%$ of the total), and practically absent as trainers, organisers or administrators («Other» in Figure 2). Although we do not have detailed information on how this may reflect the field of sports, we estimate that this lack of coverage probably does not deviate greatly from the actual female participation in sports management and organisation.

To put this into perspective, we can only rely on partial information derived from a diversity of sources. In a 2000 survey, only $1 \%$ of female members of a sports club declared an active participation in the organisation's management (Marivoet 2001). The European Institute of Gender Equality states that 'on average, in 2015, only $14 \%$ of all top decision-making positions in sports federations in Member States were occupied by women, ranging from 3\% in Poland to 43\% in Sweden' (EIGE 2015, 2). In Portugal, the percentage was slightly below the European average. Furthermore, it is estimated that there are only $20 \%$ to $30 \%$ female trainers and managers highly concentrated into certain sports - (e.g., dancing, gymnastics, figure skating and equestrianism) and they predominantly work with women, adolescents or children who compete at local and regional levels (EIGE 2015: 2). This still remains well above their level of inclusion in the analysed articles. 
Figure 2.

Role of social actors most commonly mentioned by sex

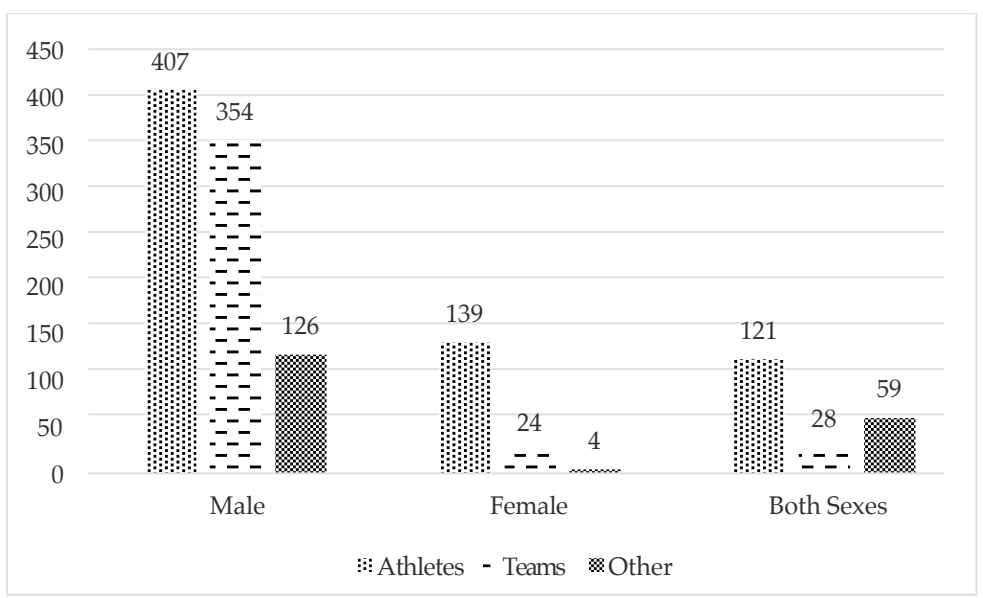

Furthermore, this focus on female sportswomen as individual athletes arises out of how some sports are inherently deemed not also as female, such as gymnastics or ice-skating, for example (Louveau 2001; Appleby et al. 2013), but also as individual. Additionally, the emphasis on one or several particular athletes enables their praising or criticising or even the focus on aspects that enable their sexual objectification (Waters and Ellis 1996; Rawjee et al. 2011; Cooky et al. 2013).

ara muitos dos amantes do ténis

ela é uma das maiores belezas do circuito feminino. Chama-se María Antónia Sánchez Lorenzo, tem 23 anos, mede $1,71 \mathrm{~m}$ e pesa $59 \mathrm{~kg}$, nasceu $\mathrm{cm}$ Salamanca e reside em Barcelona. Os portugueses ficaram a conhecie- la melhor quando venceu o Porto Ladies Open, no ano passado.

Há quem a considere bem mais sernsual do que a nussa Anna Koumikova, e a sua pela bronzeada e o cabelo castanho com madeixas loiras di-the uma imagem algo diferente das novas "barbies" do circuiro. Numa altura em que

Figure 3.

Reference to a female athlete's body in a story. ${ }^{3}$

Source: «A tímida María Antónia torce o nariz à 'Playboy'», O Jogo, page 42, April 6, 2001. ${ }^{4}$

\section{Figure 4.}

Jà á bela russa, Maria Sharapova, deu por terminada a sua campanha, ao perder com a "veterana" francesa Mary Pierce (29 anos).
Reference to a female athlete's body.

Source: «Pequeno Rochus bate 'gigante' Carlos Moya», Record, page 35 , September $5,2004 .^{5}$

It should be noted that when we talk about «women's circuit», we talk about the group of athletes participating in the women's professional tennis calendar organized by the WTA (Women's Tennis Association).

$4 \quad$ Translation of the text (Figure 3): «For many tennis lovers it is one of the greatest beauties of the women's circuit. Her name is María Antónia Sánchez Lorenzo [...]. There are those who consider her much sexier than the Russian Anna Kournikova, and her tanned skin and brown hair with blond tresses gives her a somewhat different image of the new «barbies» on the circuit».

$5 \quad$ Translation of the text (Figure 4): «The beautiful Russian, Maria Sharapova, ended her campaign by losing with French veteran Mary Pierce ( 29 years old)». 
We also found some examples of infantilization of female athletes by using their first names as seen in these examples of news headlines:

Figure 5.

Using a female athlete's first name in a news headline.

\section{ATLIISMO $\mathrm{HOJE}$ NO GRANDE PREMIO DE MARCHA DE RIO MAIOR \\ Susana tenta esquecer assalto}

Source: «Susana tenta esquecer assalto» (Susana tries to forget assault), Record, page 47, April 14, 2007.

Figure 6.

Using a female athlete's first name in a news headline.

\section{Serena... mas muito chorosa!}

Source: «Serena... mas muito chorosa!» (Serena ... but very tearful!), A Bola, page 30, June 22, 2011.

In the case of sports associated with masculine and feminine traits, we encounter clear and important differences. There are two sports especially associated with female sport: tennis - accounting for around $45.5 \%$ of the total coverage of female sport - and athletics, representing 25.7\%. Comparing with «masculine» sports, basketball leads with $32.2 \%$ of the total articles, followed by handball $(20.7 \%)$. One would expect, for example, a larger number of news on gymnastics, a sport considered predominantly feminine (Louveau 2001; Appleby et al. 2013), but these results become less surprising when taking into consideration that female athletes are mostly represented in photographs on athletics and tennis, in addition to volleyball (Coimbra 2008). Hence, we confirm that the sports deemed most feminine simply do not get news coverage.

The photographs demonstrate a lack of significant variation in the size of photographs. We also measured the letter font size of the articles and accounted for a total of 657 headlines relating to male sports in large fonts and with their highlights in bold against only 114 for female sports.

Moving onto analysis of the photographs, we evaluated photos for their representation of sexualized subjects through signifier conventions for standardised femininity, focusing on a particular body parts or accessories (backs, legs, breasts, nails, earrings or make up for example), or on whether women's pictures followed standardised patterns of idealised femininity, their bodies as «texts of femininity» (Bordo 2003). At stake is the fact that these photographs do not depict female athletes according to their sporting abilities, but as women and as feminine (Louveau 2001). 
Figure 7.

Femininity

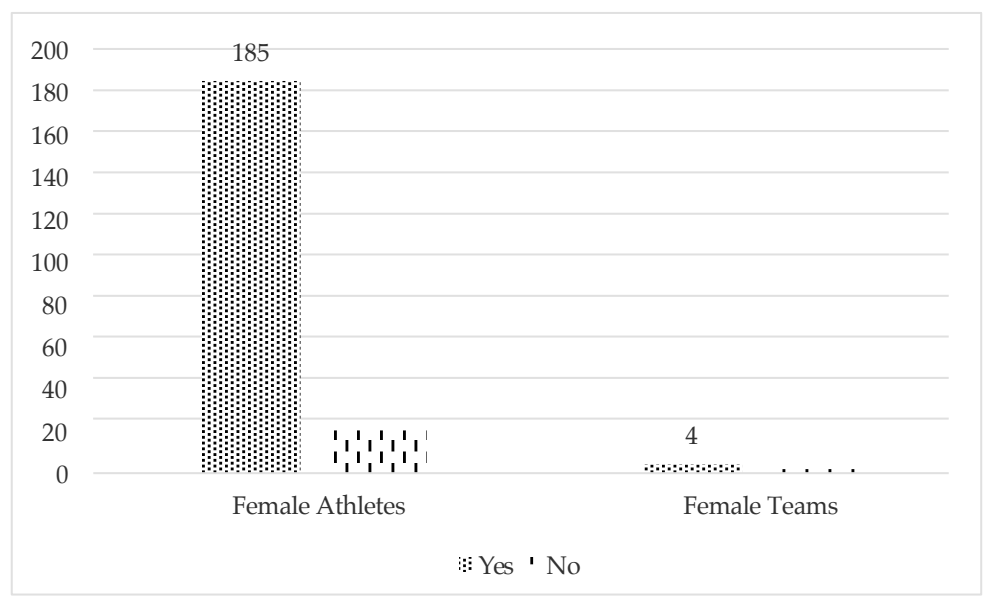

The overwhelming majority of photographs of female athletes feature idealised aspects of femininity $(90.2 \%)$. We took into account how sports such as tennis and athletics have their own clothing for women but some sports allow female accessories such as earrings or even painted fingernails, which draw attention to the athlete's femininity (Louveau 2001; Theberge 2008).

Figure 8.

Femininity of a female athlete (through the use of earrings).

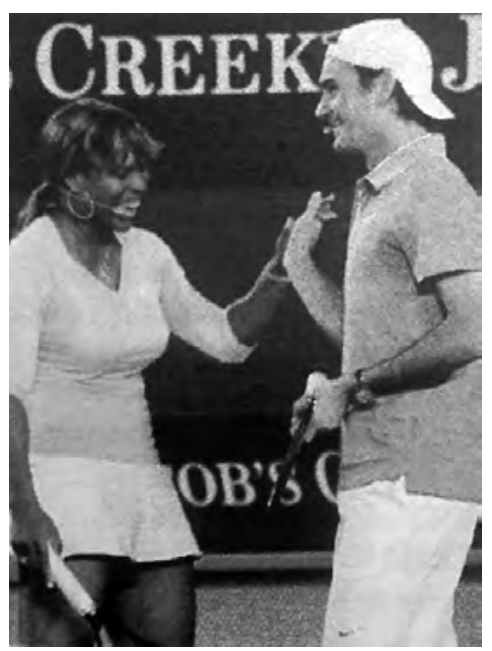

Source: «Confiante num bom resultado», A Bola, page 40, January 18, 2010.
Figure 9.

Femininity of a female athlete (through nails painted in red in the right hand «).

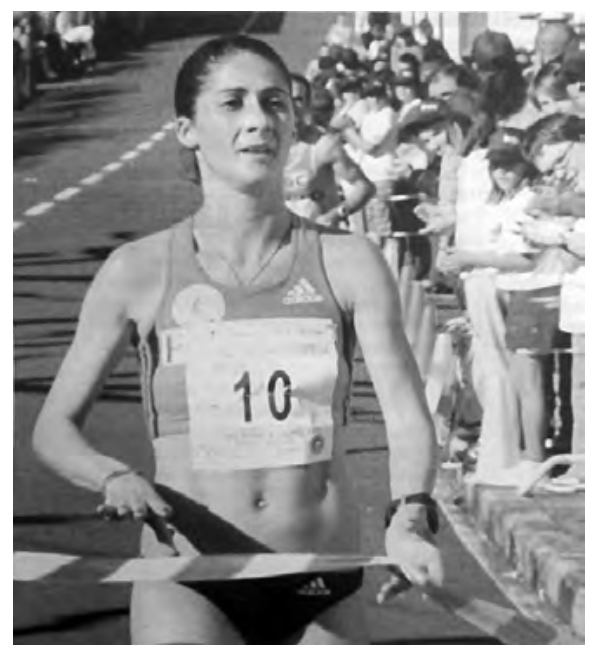

Source: "Amarelo, o sorriso...", A Bola, page 45, January 18, 2010. 
Despite the «utility» of these female bodies to sporting practices, they are still «intelligible» bodies, a Foucaultian distinction that Bordo returns to highlighting how the two versions of the female body are two sides of the same coin: «they often mirror and support each other» (Bordo 2003: 181). As athletes, they break with the social norm of their exclusion or segregation from sports, but they simultaneously become symbols of the rejection of masculinisation. Indeed, the sports integration of women has always taken place against the backdrop of warnings about the effects on their body and their sexuality. This is exemplified by the words of one of the organisers of a national sailing club: «They are champions, they're girls with good school records and success in sports and they are, in fact, very attractive and elegant women. The idea that sports make them muscular and a bit masculine is wrong» (Dias 2018, 19).

In terms of clothing, the leading category is 'short and tight-fitting' (41.2\%), corresponding all clothing (sporting or not) clearly highlighting certain parts of the body, producing a sexual objectification of female athletes. Indeed, this focus on clothing is framed by specific parts of the body - breasts, legs and sometimes the buttocks of athletes (Hargreaves 1994 apud Whannel 2008; Khomutova et al. 2015).

Figure 10.

Female athletes in short and tight clothing, which draws attention to their buttocks and legs.

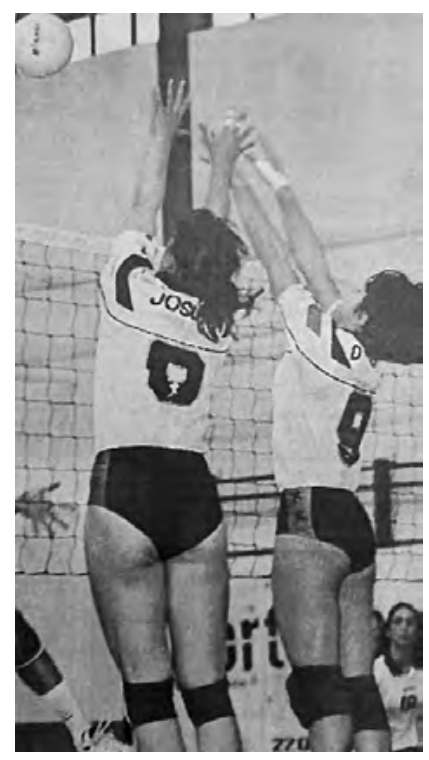

Source: «A glória no Câstelo», A Bola, page 33, March 22, 1997.

\section{Figure 11.}

Female athlete wearing tight clothing, pointing at her chest. In addition, she is photographed in pose and not in the proper movement of the sport that she practices.

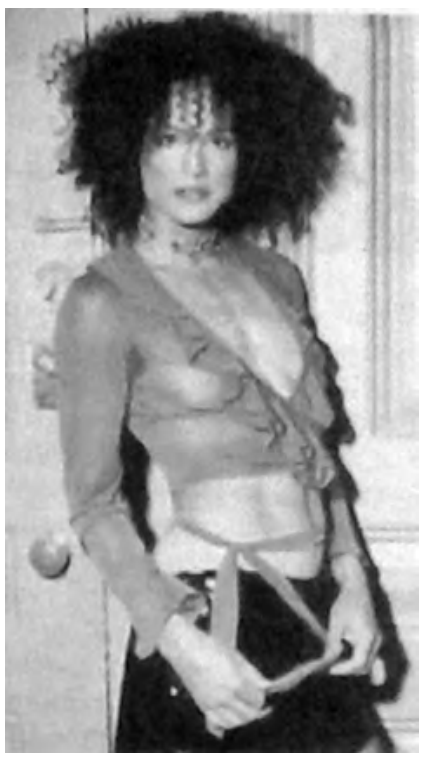

Source: «Nnenna Lynch», A Bola, page 44, April 4, 2008. 
Figure 12.

Female athlete photographed not only at the chest and face level, but also showing a part of the legs, wearing a bikini and in a passive position and sexual availability.

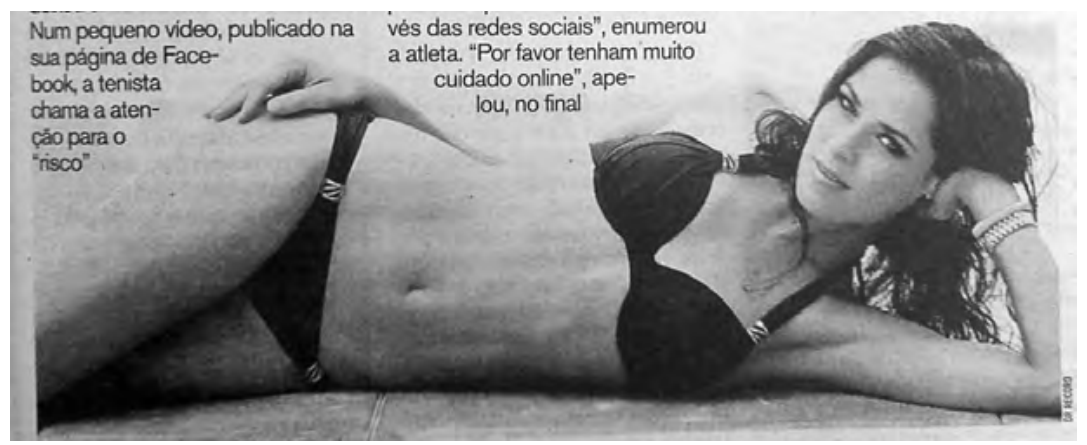

Source: «Ivanovic alerta para perigos da Internet», Record, page 37, February 13, 2015.

Another pictorial strategy conveying femininity rather than sporting performance are the athletes' poses portrayed on camera. This is observed when they are in competition or preparing to compete, or when adopting a passive pose (celebrating a victory, receiving a medal, posing for the camera) (Jones 2006).

\section{Figure 13.}

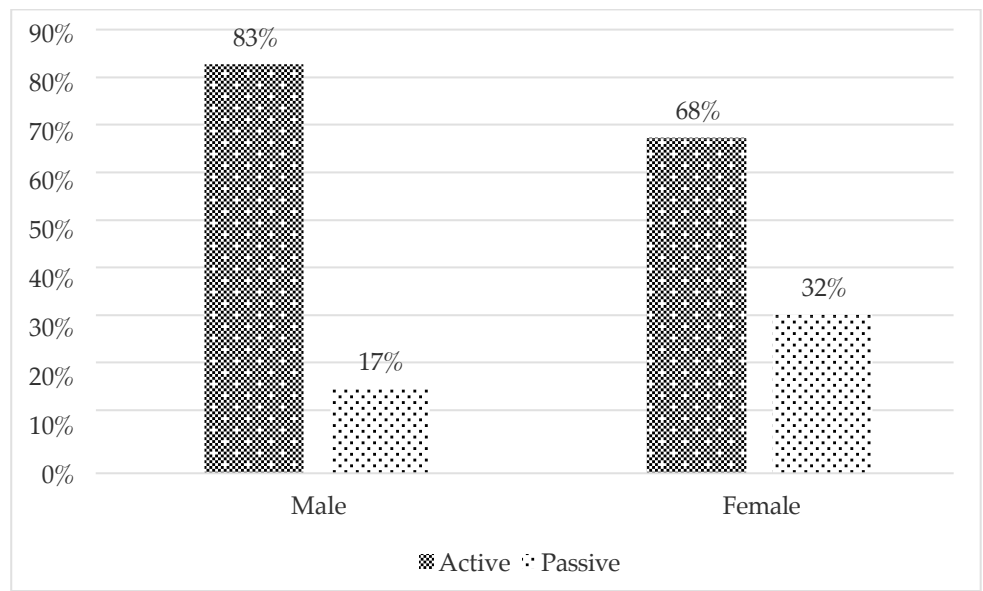

Pose in which portrayed subjects appear in the photographs

Our results show that women appear in passive positions in about $32 \%$ of photographs while male athletes portraying passivity falls back to $17 \%$. 
Figure 14:

Female athlete, portrayed as a «passive subject».

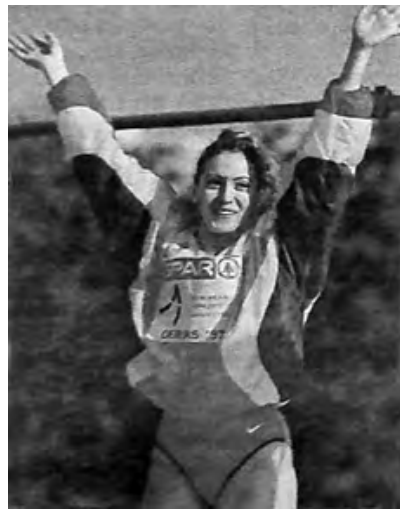

Source: 'Riad no Benfica, Mónica no Maratona', Record, page 38, October 1, 1998.
Figure 15:

Female athlete, portrayed as a «passive subject».

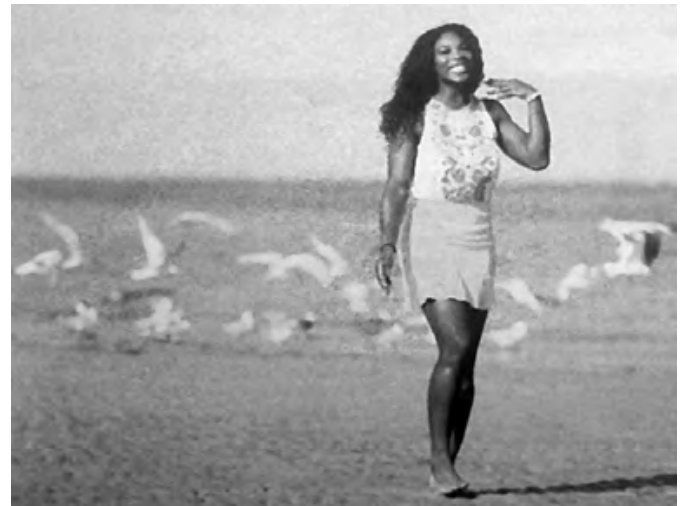

Source: «Serena cada vez mais indomável», O Jogo, page 34, April 1, 2013.

\section{Discussion}

We now seek to evaluate our hypotheses.

H1. The coverage by the written sports press perpetuates the stereotypes contained in the distinction between male and female sports through an emphasis on male athletes in certain sports and female athletes in others.

Our results show the coverage of female sports has focused primarily on individual and non-physical contact sports (tennis and athletics), as opposed to male sports coverage that places the emphasis on basketball and handball, team sports with physical contact. Hence, we confirm this hypothesis through the persistence of the stereotype that identifies sports for men as those that imply physical contact, aggressiveness and competitiveness. The assumption conveys a universalisation of the masculine worldview and a corresponding naturalisation of the relative inferiority of women who, in addition to broadly being excluded from contact sports, also face «adaptations» to some such sports (Jay 1997).

H2. The news coverage of female sports in sport newspapers has not increased in the same proportion as female participation in federated sports.

In the analysed corpus, men have higher representation (around $61 \%$ of the articles on athletes). Female athletes, are only present in a small percentage of articles (around 20.8\%). This confirm our hypothesis. 
H3. In the daily coverage of sports press, female athletes are photographed in ways that emphasise their femininity.

This hypothesis holds partially. In around 16 articles we identified expressions drawing attention to the bodies of athletes, pointing to an idealised feminine body. While few, these articles are relevant as there was no such reference to male athlete bodies. Therefore, we also confirm this hypothesis.

H4. Given the rising criticism of the sexualisation of female athletes in media coverage, it has decreased in the period under analysis.

The analysed corpus contains photographs of an implicitly sexual character of female athletes, namely through the focus on tight fitting and short clothing ( $41.2 \%$ of female athlete photographs). The ideal femininity of athletes is pictorially highlighted by portraying them firstly as women and only secondly as sportspersons (in $90.2 \%$ of the female athlete photographs). This also contributes towards their sexual objectification.

Over the period under analysis, we see how the percentage of news items on female sports undergoes small variations over the years, although there is no actual significant increase in annual totals. The articles and their accompanying photographs mostly focus female athletes in individual terms (excluding female teams).

In terms of the sexual objectification of athletes, we saw that it remained constant throughout the period of analysis, without any major changes. This, as seen above, includes the focus on short and tight-fitting clothing as well as the construction of an idealized femininity. Clearly, the usage of short and tight-fitting clothing for sporting practices does not arise from the options of either the athletes or the photographers, apart from when the athletes are photographed in their daily clothes and away from that worn on the field of competition. The usage of special equipment was from the outset and continues to be one of the criteria deployed for the segregation of female sports. Sports federations penalise any displays of disrespect of clothing rules. The study by Jay (1997) on the regulations in effect from the end of the $19^{\text {th }}$ century onwards demonstrates that the fundamental justification for determining the clothing worn by sportswomen was based on the purpose of displaying their legs while also conveying the image that this relates to female sports, played in non-aggressive styles in order to show grace, lightness and beauty. It is equally demonstrated how various sports federations have imposed such equipment with the deliberate intent of attracting the sexualised male gaze and thereby boosting the audiences for their competitions. Some athletes have expressed their displeasure at such impositions. This is the recent case of the Portuguese handball athlete who submitted a complaint to the Citizenship and Gender Equality Commission for 'having imposed on her 
clothing that sexualised the body' (Henriques 2018). This perspective ends up being assumed by the athletes themselves even when, but not necessarily, faked, and thereby reproducing this duality as regards their bodies (useful versus intelligible) and their dual identity in response to the social pressures and expectations that they face in attempts to present themselves as very feminine (skirts and long, loose hair) when they deal with the media (Goffman 1959, 1976; Cox and Thompson 2000). In a recent study about the ways in which they would like to be represented, female athletes' opinions divided over a competitive image that fosters respect for their sporting performance and a sexualised image that boosts interest given the prevailing belief that «sex sells» (Kane et al. 2013). Through the heterosexual hyper-sexualisation that they display away from competition, athletes also seek to stave off the homophobia stemming from their stereotyping as lesbians that their competitive aggressiveness and muscular appearance might otherwise trigger.

\section{Conclusions}

Our research produced the expected results alongside others that were not initially predicted.

One of the expected results, coinciding with the existing literature, relates to the level of news coverage. As identified elsewhere, there is a very low level of coverage of female sports in comparison with their male counterparts in Portugal. This appears to be more harmful given the fact that the increase in female participants in the analysed sports has not resulted in a corresponding increase of women's news coverage, perpetuating male hegemony in the news.

Also keeping with literature, the sports press in Portugal equally displays a trend towards the sexual objectification of female athletes. This clearly reflects in the news coverage of female athletes which is produced according to the normative patterns of idealised femininity, namely in terms of their poses, clothing and fashion accessories. While forecasting a reduction in the prevalence of articles and/or photographs that convey the sexual objectification of female athletes, results show a lack of clear trends, with mere slight variations over time.

Two recent studies - one on the three newspapers studied here but restricted to an analysis of a single month in 2016 (Bueno 2017) and the other focused on one newspaper in a more recent timeframe (Araújo 2017) - had similar conclusions. These trends show the lack of impact of two decades promoting gender equality among women and men (CE 2015). The continuity of sexual objectification by the media derives from a set of factors including the belief that sexualised images of women generate sales, regardless of whether these images are congruent with the actual expectations of their readers. We are also reminded that sport is an activity like any other and their participants are 'normal girls' who pursue normative 
ideals of femininity. These discursive practices, both written and visual, constitute evidence of the role played by sports in the reproduction of the prevailing gender matrix, with the likely compliance of female athletes.

This longitudinal comparative study on the journalistic coverage of female and male sports in Portugal paves the way for other studies on other types of printed media as well as analysis of television, for example, and the coverage of other sports. Football is a sport that would justify such attention given both its popularity and the victories of the national women's team. The comparison with the trends registered by Bruce (2016) and Sherwood et al. (2016) for the cases of Australia and New Zealand, respectively, would be of great interest.

Other types of printed media might adopt different coverage in terms of invisibility, trivialisation and sexualisation and should also therefore be researched. For example, Kaiser (2017) suggests that the local press, in this case the generalist newspapers with sports sections, are better focused on local or regional events and maintain a logic of proximity to local female sports and are thus able to produce a discourse freer of sexist bias and thus contributing to strengthening female sports. Testing out this hypothesis of a more positive profile in the local press and studying to what extent the looser connections in Portugal with the termed athletic-industrial complex (Zirin 2007 apud Eckstein et al. 2010: 501) would foster such an outcome. In that complex, there is a convergence of the media and the financial-economic interests that support and are supported by sport as a mass performance event. According to Pinheiro (1996), there is, in Portugal, a rising corporate dimension to the sports business and the media that promotes a mutually complicit relationship. This issue should also be researched.

More research may help to produce change, but in practical terms we should be reminded that the increasing presence of women on editorial boards potentially brings in more equalitarian visions to the task of reporting sporting activities.

\section{References}

Almeida, Cristina Matos, and Isabel Cruz. 2010. Treinadoras: Dirigir outros desafios: Situação das Treinadoras em Portugal. Oeiras: Associação Portuguesa Mulheres e Desporto.

Appleby, Karen M., and Elaine Foster. 2013. «Gender and Sport Participation». In Gender Relations in Sport, edited by Emily A. Roper, 1-20. Rotterdam: Sense Publishers. DOI: https: / / doi.org/10.1007/978-94-6209-455-0_1

Araújo, José Pedro Almeida (2017). Olhares sobre as mulheres no jornalismo desportivo: o caso do jornal Record. Dissertação de Mestrado, Escola Superior de Comunicação Social, Instituto Politécnico de Lisboa. Retrieved from: http: / / hdl.handle.net/10400.21/ 8082

Borish, Linda J. 1996. «Women at the Modern Olympic Games: An interdisciplinary look at American culture». Quest, 48, 43-56.

Bordo, Susan. 2003. Unbearable Weight: Feminism, Western Culture and the Body. $\left(10^{\text {th }}\right.$ anniversary edition). Berkeley, CA: University of California Press. 
Bruce, Toni. 2013. «Reflections on Communication and Sport on Women and Femininities». Communication \& Sport 1 (1/2): 125-137. DOI: https: / / doi.org/10.1177/216747951247 2883

Bruce, Toni. 2016. «New rules for new times: Sportswomen and media representation in the third wave». Sex Roles 74 (7-8): 361-376. DOI: https:// doi.org/10.1007/s11199-0150497-6

Bueno, Noemí Correa. 2017. Mulheres nos media desportivos: representações sobre o desporto feminino e as atletas nos jornais A Bola, Record e O Jogo. Seminar at Universidade Lusófona, Lisbon, July 11. Retrieved from http:// cpes.ulusofona.pt/pt/noticias/mulheres-pouco-representadas-nos-media-desportivos

Cardoso, Gustavo, Sandro Mendonça, Miguel Paisana, e Tiago Lima. 2014. Anuário da Comunicação 2013-2014. Lisbon: Observatório da Comunicação. Retrieved from https: / / obercom.pt/wp-content/ uploads / 2016/06/Anu\%C3\%A1rio-da-Comuniса\% C3\% A7\% C3\% A3o-2013-2014.pdf

Cardoso, Gustavo, Sandro Mendonça, Miguel Paisana, e Tiago Lima. 2016. Perfil Sociodemográfico do consumo de notícias em Portugal. Lisbon: Observatório da Comunicação. Retrieved from https://obercom.pt/wp-content/uploads/2016/06/Perfil-sociode$\operatorname{mogr} \%$ C3\% A1fico-do-consumo-de-Not $\%$ C3\% ADcias-em-Portugal- $\%$ E2\% $80 \%$ 93-Mar2016.pdf

CE - Council of Europe. 2015. Recommendation CM/Rec(2015)2 of the Committee of Ministers to member States on gender mainstreaming in sport. Retrieved from https: / / search.coe.int/ $\mathrm{cm} /$ Pages / result_details.aspx?ObjectID $=09000016805 \mathrm{c} 4721$

Centre for Gender Equality. 2006. Sports, Media and Stereotypes: Women and Men in Sports and Media [report]. Akureyri, Iceland: Centre for Gender Equality. Retrieved from http: / / www.mujerydeporte.org/documentos/docs/sms_summary_report.pdf

Coimbra, Marta I. N. G. 2008. «A imprensa escrita e o desporto: o género em questão». Lecturas: Educación Física y Deportes 122. Retrieved from http://www.efdeportes.com/ efd122 / a-imprensa-escrita-e-o-desporto-o-genero-em-questao.htm

Cooky, Cheryl, Faye L. Wachs, Michael A. Messner, and Shari Dworkin. 2010. «It's not about the game: Don Imus, Race, Class, Gender and Sexuality in Contemporary Media». Sociology of Sport Journal 27 (2): 139-159. DOI: https: / / doi.org/10.1123/ssj.27.2.139

Cooky, Cheryl, Michael A. Messner, and Robin H. Hextrum. 2013. «Women Play Sport, But Not on TV: A Longitudinal Study of Televised News Media». Communication E Sport 1 (3): 203-230. DOI: https: / / doi.org/10.1177/2167479513476947

Cox, Barbara, and Shona Thompson. 2000. «Multiple Bodies: Sportswomen, Soccer and Sexuality». International Review for the Sociology of Sport 35 (1): 5-20. DOI: https: / / doi. org / $10.1177 / 101269000035001001$

Cruz, Isabel. 2001. «Afinal, o que comemoramos?» ex æquo, 4: 7-11. Retrieved from https:/ / exaequo.apem-estudos.org/artigo/afinal-o-que-comemoramos

Dias, Tiago Mendes. 2018. «O desporto sobre as águas do Lima e do Atlântico (também) é para mulheres». Público, February 14, p. 19. Retrieved from: https:/ / www.publico. pt / 2018/02/14/local / noticia / -o-desporto-sobre-as-aguas-do-lima-e-do-atlanticotambem-e-para-mulheres-1802554

Eckstein, Rick, Dana M. Moss, and Kevin J. Delaney. 2010. «Sports Sociology's Still Untapped Potential». Sociological Forum 25 (3): 500-518. DOI: https://doi.org/10.1111/ j.1573-7861.2010.01193.x

EIGE - European Institute of Gender Equality. 2015. Gender equality in sport [fact sheet]. Vilnius: EIGE. Retrieved from https://eige.europa.eu/rdc/eige-publications/gender-equality-sport 
Fernandes, Vera F., Marcelo L. R. S. Tavares, Ayra Oliveira, and Ludmila N. Mourão. 2014. «A produção de feminilidades de atletas na Luta Olímpica». Revista Portuguesa de Ciências do Desporto 14 (S1.A): 411-420. DOI: https: / / doi.org/10.5628/rpcd.14.S1A.411

Fink, Janet S. 2015. «Female athletes, women's sport and the sport media commercial complex: Have we really 'come a long way, baby'?» Sport Management Review 18 (3): 331342. DOI: https: / / doi.org/10.1016/j.smr.2014.05.001

Goffman, Erving. 1959. The Presentation of Self in Everyday Life. New York: Penguin Books.

Goffman, Erving. 1976. Gender Advertisements. New York: Harper Torchbooks.

Gomes, Paula, Paula Silva, and Paula Queirós. 2000. Equidade na Educação: Educação Física e Desporto na Escola. Oeiras: Associação Portuguesa Mulher e Desporto.

Henriques, Joana Gorjão. 2018. «Homens foram os que mais se queixaram de discriminação.» Público, August 28. Retrieved from https://www.publico.pt/2018/08/28/ sociedade/ noticia/homens-foram-os-que-mais-se-queixaram-de-discriminacao-degenero-1841869

IPDJ - Instituto Português do Desporto e Juventude. 2018. Praticantes desportivos federados: total e algumas federações desportivas. Retrieved from https: / / www.pordata.pt/Portugal / Praticantes+desportivos+federados+total+e+por+algumas+federa $\% \mathrm{c} 3 \% \mathrm{a} 7 \%$ c3\%b5es+desportivas-2226

Jay, Jessica. 1997. «Women's Participation in Sports: Four Feminist Perspectives». Texas Journal of Women and the Law 7 (1): 19-54. Retrieved from https: / / papers.ssrn.com/sol3/ papers.cfm?abstract_id $=2128140$

Jones, Dianne. 2006. «The representation of female athletes in online images of successive Olympic Games». Pacific Journalism Review 12 (1): 108-129. Retrieved from https:/ / eprints.usq.edu.au/1054/2/Jones_PJR_2006_PV.pdf

Kaiser, Kent 2017. «Women's and Men's Prominence in Sports Coverage and Changes in Large-, Medium-, and Small-City Newspapers, Pre-and Post-Title IX: A Local Play for Equality?» Communication \& Sport 6 (6): 762-787. DOI: https: / / doi.org / 10.1177 / 216747 9517734852

Kane, Mary Jo, Nicole LaVoi, and Janet S. Fink. 2013. «Exploring Elite Female Athletes' Interpretations of Sport Media Images: A Window into the Construction of Social Identity and 'Selling Sex' in Women's Sports». Communication E Sport 1 (3): 269-298. DOI: https: / / doi.org/10.1177/2167479512473585

Khomutova, Anastasiya, and Alex Channon. 2015. «'Legends' in 'Lingerie': Sexuality and Athleticism in the 2013 Legends Football League US Season». Sociology of Sport Journal 32 (2): 161-182. DOI: https: / / doi.org/10.1123/ssj.2014-0054

Knoblauch, Hubert, Alejandro Baer, Eric Laurier, Sabine Petschke, and Bernt Schenttler. 2008. «Visual Analysis. New Developments in the Interpretative Analysis of Video and Photography». Forum: Qualitative Social Research, 9 (3): 1-14. Retrieved from http: / / www.qualitative-research.net/index.php/fqs/article/view / 1170/ 2593

LaVoi, Nicole M. 2013. «Gender and Sport Media». In Gender Relations in Sport, edited by Emily A. Roper, pp. 39-52. Rotterdam/Boston/Taipei: Sense Publishers.

Lima, Tiago. 2011. A Imprensa na Sociedade em Rede. Lisbon: Observatório da Comunicação. Retrievedfromhttps: / / obercom.pt/wp-content/ uploads / 2016/06/ A-Sociedade-emRede-Portugal-2010-A-Imprensa-na-Sociedade-em-Rede-Jul2011.pdf

Louveau, Catherine. 2001. «Desporto, Mulheres, Media: O corpo desejável das desportistas». ex æquo, 4: 57-74. Retrieved from https: / / exaequo.apem-estudos.org / files / 201711 / artigo-no-5-catherine-louveau.pdf 
Mansfield, Louise, and Helen Curtis. 2009. «Competing Women: Media representations of Femininity and National Identification at the Olympic Games in Athens 2004». Esporte e Sociedade, 12: 1-26.

Marivoet, Salomé. 2001. «O género e o Desporto: Hábitos e tendências».ex æquo, 4: 115-132. Retrieved from https: / exaequo.apem-estudos.org/files/2017-11/artigo-no-9-salome-marivoet.pdf

Mariovet, Salomé. 2003. «Assimetrias na participação desportiva: os casos de Portugal e Espanha no contexto europeu». Movimento 9 (2): 53-70. DOI: https:// doi.org/10. 22456/1982-8918.2809

Marques, Helena I. O. 2002. A Coeducação no Ensino Secundário-Estudo sobre a Actividade Física em Alunas do 12. ${ }^{\circ}$ Ano da Escola Secundária de Pombal. Dissertação de Mestrado, Universidade do Porto. Retrieved from http: / / hdl.handle.net/10216/9734

McTavish, Donald G., and Ellen B. Pirro. 1990. Contextual content analysis. Quality and Quantity 24 (3): 245-265. DOI: https: / / doi.org/10.1007/BF00139259

Messner, Michael. 2002. Taking the field: Women, Men and Sports. Minneapolis, MN: University of Minnesota Press.

Neuendorf, Kimberly. 2001. The Content Analysis Guidebook. Thousand Oaks, CA: Sage.

Paul, John; Sheets, Eric. 2012. «Adapting Erving Goffman's 'Gender Adverstisements' to Interpret Popular Sport Depictions of American Indians». International Journal of Humanities and Social Science, 2 (24): 71-83. Retrieved from http: / / www.ijhssnet.com/ journals/Vol_2_No_24_Special_Issue_December_2012/10.pdf

Pedersen, Paul M. 2002. Examining Equity in Newspaper Photographs. International Review for the Sociology of Sport 37 (3-4): 303-318. DOI: https:// doi.org/10.1177/10126902 02037004895

Pinheiro, Maria Cláudia Brandão. 1996. «Os media e o desporto: Análise dos Géneros Masculino e Feminino nos Jornais Desportivos». In Actas do III Congresso Português de Sociologia. Oeiras: Celta Editora. Retrieved from https://aps.pt/wp-content/ uploads / 2017/08/DPR492edd6946cdd_1.pdf

Rawjee, Veena P., Nisha Ramluctman, and Nereshnee Govender. 2011. «Missing in Action: The Portrayal of Women in Sport in the Print Media». Loyola Journal of Social Sciences, 25 (2): 176-190.

Santos, Susana. 2006. Dietas de Media em Portugal: televisão, imprensa, rádio e internet. Lisbon: Observatório da Comunicação. Retrieved from https://obercom.pt/wp-content/ uploads / 2016 / 06 / Dietas-de-Media-em-Portugal-televis\%C3\% A3o-imprensa-r\%C3\%A1dio-e-internet-\%E2\%80\%93-Nov2006.pdf

Sherwood, Merryn, Angela Osborne, Mathew Nicholson, and Emma Sherry. 2016. «Newswork, News Values, and Audience Considerations: Factors That Facilitate Media Coverage of Women's Sports». Communication $\mathcal{E}$ Sport 5 (6): 647-668. DOI: https:/ / doi.org/10.1177/2167479516645535

Theberge, Nancy. 2008. «Gender and Sport». In Handbook of Sport Studies, edited by Jay Coakley and Eric Durning, 322-333. Los Angeles, CA: Sage.

Trolan, Eoin J. 2013. «The impact of the media on gender inequality within sport». ProcediaSocial and Behavioral Sciences 91: 215-227. DOI: https://doi.org/10.1016/j.sbspro.2013.08.420

Waters, Judith, and George Ellis. 1996. «The Selling of Gender Identity». In Advertising and Culture. Theoretical perspectives, edited by Mary Cross, 1-10. Westport, CN: Praeger. Retrieved from http:/ / ruby.fgcu.edu/courses/tdugas/ids3301/acrobat/gender.pdf Weber, Robert. 1990. Basic content analysis. 2nd ed. Newbury Park, CA: Sage. 
Whannel, Garry. 2008. «Sport and the Media». In Handbook of Sport Studies, edited by Jay Coakley and Eric Durning, 291-308. Los Angeles, CA: Sage.

Pedro Saraiva. PhD student of Sociology, Faculty of Economics, University of Coimbra

Electronic address: pdgs@outlook.pt

Virgínia Ferreira. Sociologist. Assistant Professor, Faculty of Economics, University of Coimbra, Portugal. Using both qualitative and quantitative methods, her research has focused on the feminization of occupations, the changing patterns of sexual segregation of labour market and employment, and to the evolution of equality public policies. Since 2004, she is member of the European Commission Expert Group on Gender and Employment. She has led and participated in several national and international research projects.

Electronic address: virginia@fe.uc.pt

Maria João Silveirinha. Associate Professor, Department of Philosophy, Communication and Information of the Faculty of Arts and Humanities, University of Coimbra. Head of the Doctoral Programme in Communication Sciences. Her research interests are on feminist media studies, media representations and political and social aspects of the media public sphere. She is the author of several books and articles in this field. She has led and participated in national and international research projects on Communication and the Media.

Electronic address: mjsilveirinha@gmail.com

Article received on the 31st of May and accepted for publication on the 23rd of October 2019. 